\title{
Nietzsche, Heidegger and the Eternal Return
}

\author{
Aaron Dopf \\ The University of Kansas
}

There is little doubt that Nietzsche was a major influence on Heidegger. In his work Nietzsche, however, Heidegger is guilty of nothing less than a gross misinterpretation of Nietzschespecifically on the issue of the eternal return. This misinterpretation arises out of an attempt to appropriate Nietzsche and reinterpret him in such a way that he is rendered a prelude to Heidegger's own philosophy. Whether willful or not, Heidegger's misinterpretation of the eternal return is the result of his reckless interpretive method, his failure to consider the many facets of Nietzsche's thought, and his insistence on interpreting Nietzsche on purely metaphysical grounds.

The goal of Heidegger's analysis of Nietzsche is to first prove that the eternal return was a metaphysical doctrine, and second, not only to harmonize this interpretation with the rest of Nietzsche's philosophy, but to attempt to prove that this harmonization lies at the heart of Nietzsche's philosophy as the revaluation of all values. "The doctrine of the eternal return of the same coheres in the most intimate way with that of will to power. The unity of these teachings may be seen historically as the revaluation of all values hitherto" (Heidegger I 18). This however is quite an undertaking since, on close examination, the eternal return and the will to power seem mutually exclusive; for, the eternal return would 'cap,' or conclude, the infinitely variable flux of the will to power as always becoming-often described by Nietzsche in appealing to Heraclitus.

Heidegger discusses this in relation to Alfred Baeulmer. He quotes Alfred Baeumler's claim that "only one can be valid: either the doctrine of eternal return or the doctrine of will to power" and adds to that, "According to Baeumler's account, the doctrine of eternal recurrence implies bringing Becoming to a standstill. With his either/or, Baeumler presupposes that Heraclitus teaches the 
eternal flux of things, in the sense of the ever-ongoing" (I 22). But what other way is there to interpret Heraclitus? Heraclitus did not say "one can't step into the same river twice... that is, until the same river returns" for the whole point of his aphorism is that the same river will never return. Consider Richard Geldard's mature interpretation of Heraclitus:

All things change, is one idea. All things are in flux is another. If things changing are also in flux, then the condition is totally fluid. The change is changing. Opposites are only momentarily in tension; they next become identical, as one thing becomes another before either can be identified as one thing or another. My joy contains sorrow even before its sweetness can be fully savored. (Geldard 52)

This reading of Heraclitus resonates acutely with Nietzsche's project of life affirmation (to be discussed later) and the whole of his philosophy. It therefore seems to be exactly what Nietzsche had in mind when he referenced Heraclitus, in contrast to Heidegger's interpretation.

Nevertheless, Heidegger maintains that, not only are the two doctrines reconcilable, but their reconciliation is the very heart of Nietzsche's philosophy.

Now, if we do not thoughtfully formulate our inquiry in such a way that it is capable of grasping in a unified way the doctrines of the eternal return of the same and will to power, and these two doctrines in their most intrinsic coherence as revaluation... then we will never grasp Nietzsche's philosophy (I 17).

The coherence of the two is then understood in terms of the nature of being such that:

The determination "will to power" replies to the question of being with respect to the latter's constitution; the 
determination "eternal recurrence of the same" replies to the question of being with respect to its way to be. Yet constitution and manner of being do cohere as determinations of the beingness of beings (II 199).

But why could 'the way' of being not just as easily be, not recurrence, but an eternal and ever changing flux? Here Heidegger is being more or less dogmatic and offers nothing to justify this claim. Moreover, this presents Heidegger with a problem; such a claim contradicts the general understanding of being described by Heraclitus in the traditional interpretation-the same one presumably affirmed by Nietzsche.

Therefore, Heidegger regularly appeals to what has been called 'the recapitulation aphorism' in attempting to distance Nietzsche's conception of becoming from the traditional Heraclitean conception so that Nietzsche's conception of becoming can be harmonized with Heidegger's conception of Being.

Nietzsche does not cling to such a position [the character of beings is Becoming] -although that is usually what we are thinking when we associate him with Heraclitus. Much to the contrary, in a passage purposely and expressly formulated to provide an encompassing overview (WM, 617), Nietzsche says the following: "Recapitulation: To stamp Becoming with the character of Being - that is the supreme will to power." This suggests that Becoming only is if it is grounded in Being as Being: "That everything recurs is the closest approximation of a world of Becoming to one of Being:-peak of meditation" (I 19).

The recapitulation aphorism serves as the justification for Heidegger's ontological rendering of Nietzsche's eternal return. This metaphysical interpretation proceeds as follows:

"Recurrence" thinks the permanentizing of what becomes, thinks it to the point where the becoming of what becomes is secured in the duration of its becoming. The "eternal" 
thinks the permanentizing of such constancy in the direction of its circling back into itself and forward toward itself. Yet what becomes is not the unceasing otherness of an endlessly changing manifold... Nietzsche's thought links the constant permanentizing of the becoming of whatever becomes into the only kind of presence there is-the self-recapitulation of the identical... The thought of return is not Heraclitean in the sense usually expounded by our historians of philosophy (III 164-165).

Heidegger cannot deny the influence of Heraclitus on Nietzsche, nor can he deny the conflict that arises between the traditional interpretation of Heraclitus and his rendering of Nietzsche; thus in order to appropriate Nietzsche, he must first appropriate Heraclitus. One additional point of consideration: if Nietzsche was working with something other than the traditional understanding of Heraclitus, why didn't he ever discuss this? The truth is, Heidegger achieves the metaphysical unity of the eternal return and the will to power only by misinterpreting both Nietzsche and Heraclitus. Regardless, Heidegger conceives of this unity as follows:

If being as such is will to power and thus eternal return Becoming, and if will to power demands end-lessness and excludes endless progress toward an end itself; if at the same time the eternal Becoming of will to power is delimited in its possible configurations and constructs of domination, because it cannot be new unto infinity; then being as a whole as will to power must permit the same to recur and must be an eternal return of the same. This "circuit" embodies the "primal law" of beings as a whole, if being as such is will to power (III 211-212).

Thus, for Heidegger, it's only through metaphysically harmonizing the eternal return with the will to power that the true meaning of the will to power reveals itself. In Heidegger's words, "What is will to power itself, and how is it? Answer: the eternal 
recurrence of the same" (I 19). To which he adds: "Whoever neglects to think the thought of eternal recurrence together with will to power, as what is to be thought genuinely and philosophically, cannot adequately grasp the metaphysical content of the doctrine of will to power in its full scope" (I 21). This is quite a revolutionary conclusion to draw-but a conspicuously suspicious conclusion in that, not only does the conclusion rely on controversial readings of both Heraclitus and Nietzsche, but it is based entirely on one single note in a collection of unpublished notes for which the purpose can never be known definitively.

Moreover, Heidegger resigns his discussion of Nietzsche to purely metaphysical grounds-"Like all Western thought since Plato, Nietzsche's thinking is metaphysics" (III 187). But Nietzsche was much more than a metaphysician (if he can be called one at all), and operated on many levels. This bias of Heidegger causes him to misread the recapitulation aphorism and, consequently, the whole of Nietzsche's philosophy, for it is all interpreted by Heidegger through the lens of the recapitulation aphorism-making the eternal return the center of Nietzsche's thought.

In opposition to all the disparate kinds of confusion and perplexity vis-a-vis Nietzsche's doctrine of return, we must say at the outset, and initially purely in the form of an assertion, that the doctrine of the eternal return of the same is the fundamental doctrine in Nietzsche's philosophy (II $6)$.

More than just a philosopher, however, Nietzsche was a psychologist and a religious investigator as the title of Kaufman's book, Philosopher, Psychologist, Antichrist, reminds us. Thus any doctrine or thought of Nietzsche's has the potential to operate on multiple levels and must be considered, not just metaphysically, but psychologically. Heidegger misinterpreted Nietzsche as the 'last metaphysician' when it was in fact metaphysics that Nietzsche rebelled against. This makes Nietzsche unique in the philosophical tradition and demands that he be treated uniquely. Thus, Nietzsche is radically misunderstood if he is forced into the framework of 
the rest of the continental tradition - that is, if he is 'systematized,' which is exactly what Heidegger attempts to do. Heidegger sought to 'domesticate' Nietzsche's thought-in other words, take his words, and his truths, merely at face value. But it is only through the unadulterated instincts of thought (i.e. the natural balance of Dionysiac and Apolline elements, or passion and reason), so to speak, that Nietzsche reveals his truths. Thus Nietzsche defies systematization, and irony, satire and sarcasm are his greatest allies-all of which unfortunately lends him all too easily to misinterpretation by those who are intellectually cheap or superficial. Moreover, it is ironic to attempt to systematize him in that, not only did Nietzsche consider himself 'a-systematic,' but his primary concern-his entire project-was to deconstruct and undo the intellectual domestication begun by Plato and Christianity - the 'improvers' of mankind.

The question, however, remains: how then should we treat the recapitulation aphorism? First, one must consider it in light of certain aspects of human nature discussed by Nietzsche - one must, that is, examine it psychologically. First Nietzsche observes, "Need for communication as necessary for human survival led to the falsification of reality" (GS 354) and thus where humans are concerned "the conditions of life might include error" (GS 121) because of the crooked path the will to power has taken in human all too human expression. "As the most endangered animal, he needed help and protection, he needed his peers, he had to learn to express his distress and to make himself understood.... thinking takes the form of words" (GS 354). But words corrupt reality. "He [man] really thought that in language he possessed knowledge of the world... A great deal later-only now-it dawns on men that in their belief in language they have propagated a tremendous error (HH 11)." This error of practical convention has caused the will to power to express itself in a corrupted form in humans such that "stamping being on becoming" has proved advantageous and therefore become the highest expression of the will to power in human life. But this does not change the fact that the will to power as an unadulterated metaphysical expression in fact defies beingas Nietzsche says "there is no being, only becoming." Thus, the 
recapitulation aphorism applies to human psychology but not metaphysics as Heidegger interprets it.

Moreover, Heidegger insists on interpreting even the 'difficulty' of thinking the eternal return in terms of metaphysicsthat is, in terms of being and time.

When he thinks "the most difficult thought" at the "peak of meditation," Nietzsche thinks and meditates on Being, that is, on will to power as eternal recurrence. Thinking Being, will to power, as eternal return, thinking the most difficult thought of philosophy, means thinking Being as Time. Nietzsche thinks that thought but does not think it as the question of Being and Time. Plato and Aristotle also think that thought when they conceive Being as ousia (presence), but just as little as Nietzsche do they think it as a question (I 20).

Heidegger completely misinterprets Nietzsche, manipulating his work to serve as merely an unwitting preface to his own work and alludes to the notion that somehow Nietzsche's work is devoid of substantial content unless it is seen in the light of Heidegger's analysis of being.

The reason for this [Nietzsche failing to think the eternal return as a question of Being] is not that the thought remained in any way obscure to him, but that like all metaphysicians prior to him Nietzsche was unable to find his way back to the fundamental traits of the guiding metaphysical projection (III 164).

But Nietzsche's project was something very different. Thus, he did not conceive of his project as 'the question of Being and Time' though Heidegger dogmatically insists he did and proceeds from this to reconstruct Nietzsche's unpublished writings according to this agenda. "...The book [The Will to Power] merely leads us to the threshold of the question, not yet into the question itself" (I 21). Heidegger's misunderstanding of Nietzsche is explained by 
the fact that his analysis is not the result of interpretation but of appropriation.

It should further be noted that Heidegger's analysis of Nietzsche makes great use of Nietzsche's unpublished notes, collected in the posthumous work The Will to Power. Heidegger argues, "If our knowledge were limited to what Nietzsche himself published, we could never learn what Nietzsche knew perfectly well, what he carefully prepared and continually thought through, yet withheld" (II 15). But on this point there are a number of important things one should take into consideration. First, Nietzsche, perhaps more so than any other philosopher, was acutely concerned with what he published. Add to this the fact that Nietzsche was a ferociously avid writer who frequently jotted notes during walks that very often amounted to little in his estimation. Nevertheless he felt a certain sentimental attachment to them and believed they still had value in documenting the journey of his thoughts. Thus he kept virtually all of them-including the ones he felt were not only wrong, but even ridiculous. Above all, however, one must take into consideration the fact that Nietzsche's use of irony and sarcasm makes it very easy to misinterpret him out of the context of the work in which they are contained. Thus, when we speak of his unpublished notes we simply cannot make any definitive conclusions about their meaning and are left dangerously susceptible to interpreting them within an imposed context of our own choosing. For these reasons, here is the proposed method for treating Nietzsche's doctrine of the eternal return: give primacy to the published texts, determine the nature and function of the eternal return strictly within their domain, and then inspect The Will to Power to see if anything there is sufficient to refute or modify the previous determinations. Heidegger failed to properly understand the doctrine because, in contrast to this approach, his method was to construct the raw material of The Will to Power in accordance with his own project and interpret the rest of Nietzsche according to that construction such that Nietzsche was rendered a prelude to Heidegger's own work Being and Time.

In light of this proposed method let us then answer Heidegger's question: 
But even if we concede that here we have a contradiction which cannot be transcended and which compels us to decide in favor of either will to power or eternal recurrence, why does Baeumler then decide against Nietzsche's most difficult thought, the peak of his meditation, and for will to power (I 22)?

There are many reasons for favoring the will to power over the eternal recurrence. Not only are "proofs" for its literal existence pathetic and easily refutable, they fly in the face of the rest of Nietzsche's philosophy. The proof is found in The Will to Power where Nietzsche says:

If the world may be thought of as a certain definite quantity of force and as a certain definite number of centers of force... it follows that, in the great dice game of existence, it must pass through a calculable number of combinations. In infinite time, every possible combination would at some time or another be realized; more: it would be realized an infinite number of times (WP 1066).

This however clashes with Nietzsche's refusal to accept the notion of atoms or any "definite number of centers of force." Rather, according to Nietzsche these are merely convenient modes of interpreting reality that in fact distort reality's true nature as a continual flux. "We operate only with things that do not exist: lines, planes... atoms... In truth we are confronted by a continuum out of which we isolate a couple of pieces (GS 112)." But even if Nietzsche believed reality was composed of finite atomistic components (which he clearly did not) this still would not prove the doctrine of the eternal return. As any mathematician will tell you, a finite set can still produce an infinite number of combinations and never need repeat.

Moreover, the doctrine is logically inconsistent with other claims of Nietzsche's. Richard Howey observes: 
If each event in every existence is but a repetition of a previous cycle, then everything is already determined including all the individual acts of Willing. If, then, we interpret the doctrine of Eternal Recurrence literally, there can never be a Superman, for Zarathustra himself says: 'Never yet has there been an overman...' Clearly Nietzsche could not have meant the doctrine of Eternal Recurrence to be interpreted literally as absolute determinism. Ultimately Heidegger leaves this question suspended and says that Nietzsche never pursued the problem of these connections (Howey 96).

Let us then appeal to Occam's Razor. Is it simpler to believe that a man as brilliant as Nietzsche overlooked an obvious contradiction within his philosophy and really believed in the soundness of such easily refuted arguments, or is the explanation simply that Nietzsche had other intentions with the doctrine than for it to be taken metaphysically literally?

So if the doctrine of the eternal return cannot be taken metaphysically literally, does it follow, as Heidegger believes, that for anyone who subscribes to this:

In the latter case [maintaining that the eternal return is metaphysically unsound] they explain the doctrine as an impossible eccentricity of Nietzsche's, something that can count only as a personal confession of faith and does not pertain to the system of Nietzsche's philosophy proper (II 5).

But is there another possibility? Just because the eternal return cannot be reconciled with Nietzsche's metaphysics, does it have no place in his philosophy? Is it then something that must be explained away in order to maintain the integrity of Nietzsche's philosophy? This follows only if one reduces Nietzsche to a metaphysician. But he was much more than this and his project cannot be understood on any single level-particularly a metaphysical one. One must take into account the psychological 
aspects of Nietzsche's thought-something Heidegger utterly failed to do. If one does this, the eternal return can be reconciled with the will to power. But this endeavor should not be interpreted as apologizing for some deficiency of Nietzsche's thought; far from it, this reconciliation is the very road he intended the free spirit to walk - the greater truth of Nietzsche's thought is in fact revealed in this very reconciliation. Thus, the two doctrines can and must be unified, but not on a metaphysical level. The will to power is a metaphysical doctrine but the eternal return is not-it is a psychological one. Heidegger's mistake is that he tries to assimilate the two on equal footing within a purely ontological frameworkthis reveals the bias that prevented him from properly interpreting Nietzsche, and why he could only make Nietzsche intelligible within his own operative framework.

So how then is the eternal return to be understood within Nietzsche's framework? To determine this, as previously discussed, the best method is to analyze it first according to how it is presented in Nietzsche's published works. In The Gay Science it's introduced as the heaviest burden:

The greatest weight [heaviest burden]. - What, if some day or night a demon were to steal after you into your loneliest loneliness and say to you: "This life as you now live it and have lived it, you will have to live once more and innumerable times more...

Would you not throw yourself down and gnash your teeth and curse the demon who spoke thus? Or have you once experienced a tremendous moment when you would have answered him: "You are a god and never have I heard anything more divine." If this thought gained possession of you, it would change you as you are or perhaps crush you. The question in each and every thing, "Do you desire this once more and innumerable times more?" would lie upon your actions as the greatest possible weight. Or how well disposed would you have to become to yourself and to life to crave nothing more fervently than this ultimate eternal confirmation and seal (GS 341)? 
The important question in uncovering the meaning of this passage is: what does Nietzsche mean by 'burden' - is this a metaphysical burden or psychological one? Considering that the focus of the passage is clearly on one's reaction to the eternal return, it seems obvious that it is offered as a thought experiment and not a metaphysical reality. Heidegger however falsely interprets the 'burden' metaphysically: "The thought of eternal return is to be a burden - that is, is to be determinative-for our envelopment within beings as a whole" (II 22). In contrast to this erroneous interpretation of the eternal return, Milan Kundera in his book The Unbearable Lightness of Being, perfectly expresses the nature and significance of this 'burden.'

If eternal return is the heaviest of burdens, then our lives can stand out against it in all their splendid lightness. But is heaviness truly deplorable and lightness splendid? The heaviest of burdens crushes us, we sink beneath it, it pins us to the ground. But in the love poetry of every age, the woman longs to be weighed down by the man's body. The heaviest of burdens is therefore simultaneously an image of life's most intense fulfillment. The heavier the burden, the closer our lives come to the earth, the more real and truthful they become. Conversely, the absolute absence of a burden causes man to be lighter than air, to soar into heights, take leave of the earth and his earthly being, and become only half real, his movements as free as they are insignificant... The only certainty is: the lightness/weight opposition is the most mysterious, most ambiguous of all (Kundera 5-6)

It is this ambiguity that Nietzsche is playing with. As we shall see, it is in fact through this ambiguity that the significance of the eternal return - the reason it is the 'peak of meditation'-reveals itself. And this ambiguity is a psychological, not a metaphysical, phenomenon.

The psychological interpretation of the eternal recurrence is further supported by the character of other published passages in 
which it is discussed. In Beyond Good and Evil Nietzsche says, "who wants to have it again as it was and is to all eternity, insatiably calling out da capo... (BGE 56). Then in Thus Spoke Zarathustra Nietzsche says, "Courage, however, is the best slayer-courage which attacks: which slays even death itself, for it says, 'Was that life? Well then! Once more!' "(PN 269). In all three discussions it is again the reaction that matters-the eternal return is simply a means to this end; it's simply the litmus test for courage and life affirmation-the virtues of the Übermensch.

But why is such a thought experiment necessary? To answer this one must examine the context of the work within which the doctrine is first presented by Nietzsche, The Gay Science. Consider first, however, Heidegger's description of the context of The Gay Science.

Now we are better prepared to grasp the reason why Nietzsche communicates this demonic thought only at the conclusion of The Gay Science: what is referred to here at the conclusion is-in terms of the matter-not the end but the beginning of the "gay science," its commencement and its end alike. The matter in question is the eternal return of the same, which the "gay science" must come to know, first and last, if it is to be proper knowing. "Gay science" is for Nietzsche nothing other than the name for that "philosophy" which in its fundamental doctrine teaches the eternal return of the same (II 21).

For Heidegger the context just is the doctrine itself-that just is the "gay science." But Heidegger has completely neglected what is in fact the heart of the froelichen Wissenschaft-namely the death of God, which is the context of The Gay Science. It is within that context that the eternal return is to be understood-it is invoked to awaken us to the reality and weight of this truth.

The eternal return is not a metaphysical reality but a psychological thought experiment designed to retrain us in the ways of life affirmation. It has only corrective application. How would you live if you knew it would be repeated forever? According to 
Nietzsche, you should already be living your life in this manner and would if it wasn't for the corruption of Christianity and its creation of God and the 'other worldly' which reduce this world to a mere means. Thus one rejects the eternal return (and therefore negates life) to the extent that they affirm the next world-this rejection and life negation is a symptom of humanity's decadence.

What? Is humanity itself decadent? Was it always?What is certain is that it has been taught only decadent values as supreme values. The morality that would unself man is the morality of decline par excellence-the fact, "I am declining," transposed into the imperative, "all of you ought to decline"-and not only into the imperative.-This is the only morality that has been taught so far, that of un-selfing, reveals a will to the end; fundamentally, it negates life (GM 333).

Nietzsche sees his project as attempting to overcome the fall of humanity into this decadence-and the eternal return is designed to test the extent to which one has been affected and become "human all too human". It is designed to test one's life affirmation. Nietzsche created it simply to counteract the Christian doctrine of the next world. It was as if he was saying, "Ok, you have your dogmatic belief in the next world and now I will mock you with my dogmatic belief in the eternal return." The eternal return was conceived by Nietzsche simply in response to the doctrine of the next world. Where the next world is the doctrine of supreme life negation, Nietzsche sees the eternal return as the doctrine of life affirmation. Neither, however, is metaphysically true for Nietzsche, and if we had remained faithful to our instincts we would not have needed the eternal return in the first place.

The death of God heralds a return to the instincts and life affirmation-but it's dangerous. Consider Dostoyevsky's claim, "Without God everything is permissible." In the wake of the death of God we are left with the burden of responsibility - where 'God' had formerly been the apparatus of our own devices by which we avoided this responsibility. 'God' was a concept born of the human 
mind, for Nietzsche; therefore it can perish from the mind-or in other words, die. Previously God provided the weight for our existence; and to have his existence lifted would be too dramatic were it not for the eternal return to keep us grounded. The eternal return is now the heaviest burden which lends weight to actions (something already present in those who affirm life) and forces us to ask ourselves, "All may be permissible but what is it I wish to will-what would I will to repeat forever?" According to Nietzsche, this has been the question all along, for everything has always in fact been permissible, we have just sought refuge from this responsibility and burden, in the catacombs of Christian dogma and western metaphysics. The death of God (the realization that he was our own creation) shatters these illusions and makes life affirmation the new challenge.

The overman is the meaning of the earth... I beseech you, my brothers, remain faithful to the earth, and do not believe those who speak to you of other-worldly hopes!... Once the sin against God was the greatest sin; but God died... To sin against the earth is now the most dreadful thing (PN 125).

The eternal return is simply our means to this affirmation. It's Nietzsche's way of retraining the instincts-a noble lie that will help us navigate the dangerous waters of this transitional period back to our instincts without falling into the abyss of nihilism. We have become so dependent on God and divine law that giving it up would leave us in a very precarious position. As Nietzsche describes through Zarathustra, "Man is a rope, tied between beast and overman-a rope over an abyss. A dangerous across, a dangerous on-the-way, a dangerous looking-back, a dangerous shuddering and stopping" (PN 126). Zarathustra, with his doctrine of the eternal return, is meant to guide us through this treacherous existential journey and back to the instincts and life affirmation.

How is affirmation to be attained then? By complete affirmation of a single moment which, if properly understood, simultaneously affirms the totality of all moments, and therefore, 
all life making it the highest expression of the will to power. In so far as one is living for the future they are betraying and negating the present. And why would one be living only for the future? Answer: because they are incapable of handling the suffering that attends and is intertwined with the present. This immaturity is then amplified by doctrines of the next world-where one is no longer even living for tomorrow, but for the next world. When this has occurred one has negated life out of an inability to handle suffering. Thus, Nietzsche observes, the eternal return forces one to confront their suffering since it will return and live on eternally. This makes it the most horrible thought for those who have sought refuge in the next world. The eternal return awakens one to the fact that not only is all life imbued with suffering, so is all joy. "As deeply as man sees into life, he also sees into suffering" (PN 269). Thus, affirming a single moment, affirming the present, brings with it affirmation of all life with the understanding that everything is inseparably intertwined-joy in suffering and suffering in joy.

Consider, for example, an analogy from music. The cadence of a piece of music does not, so to speak, "do away with" all the notes that came prior to it. It does not stand alone, but is made significant simply by subsuming the prior movements of harmony, and resolutions of dissonance, in a final culmination. That is, its value and beauty lies, not in itself, but in its relationship to both consonance and discord-in itself it is meaningless and aesthetically uninteresting. The true significance of, say, the infamous Tristan Chord, therefore, is contained, not within itself, but within the entirety of Wagner's Tristan and Isolde-its apparent autonomy is merely an illusion in so far as its aesthetic value is concerned. Thus, a piece of music does not "do away with" discord, or move beyond it, but resolves and overcomes discord. To apply this to life then, Nietzsche's charge against Christianity is that, with its doctrine of "the next world," it is continually trying to "do away with" the past and with suffering in a futile, but destructive, attempt to isolate and abstract pure joy (i.e. heaven and eternal bliss). The danger of Christianity, therefore, is that it is mature enough to recognize the beauty of the Tristan Chord but too 
immature to handle its beauty. The doctrine of the eternal return, therefore, is designed to force one to confront their sufferings rather than flee from them into tomorrow or the next world, and for the first time be able, not merely to recognize joy, but handle it. Only in so doing is one able to truly appreciate the full significance of their joys-joys which are, ironically, negated if one attempts to isolate and flee to them out of immature lust. Interestingly enough, to carry the analogy one step further, is the value and significance of a piece of music not measured by the very degree to which it cries out "da capo!"?

Thus, joy and suffering are contained within one another and cannot truly be isolated. As Geldard described in relation to Heraclitus' flux, "My joy contains sorrow even before its sweetness can be fully savored." Since life is unified in the eternal flux of things, one can only affirm their joy by simultaneously accepting their suffering. This is the reality that the eternal return reminds us of; it simply will not allow one to escape their suffering, and points out that by trying to escape it one is merely betraying their joys - living for the next world may sedate one to suffering, but it also sedates them to fully experiencing joy. According to Nietzsche this was understood instinctively until it was corrupted by Christianity with its beliefs in the next world out of an inability to handle suffering, and therefore also joy-and therefore also life itself. The eternal return is simply a synthetic way to mimic that instinctive understanding and usher in the possibility of genuine life affirmation. As Nietzsche artfully describes in Zarathustra:

Have you ever said Yes to a single joy? O my friends, then you said Yes too to all woe. All things are entangled, ensnared, enamored; if ever you wanted one thing twice, if ever you said, "You please me, happiness! Abide, moment!" then you wanted all back. All anew, all eternally, all entangled, ensnared, enamored-oh, then you loved the world (PN 435).

Therefore, Amor fati, not the eternal return, is the essence of Nietzsche's philosophy. And it expresses itself completely in " $d a$ 
capo"-and through them life is affirmed in the moment by embracing the whole of one's existence through a single justifying joy. This is life affirmation, and this is Nietzsche's project in the wake of the death of God-and this is all sadly overlooked by Heidegger. The eternal return is significant simply as the first step-a corrective step-towards the ultimate ideal of life affirmation expressed in Amor fati.

Thus, ironically it is the metaphysical paradox of the will to power and the eternal return that conveys the ultimate truth. Once one has become strong enough to see the paradox and the conflict of the will to power and the eternal return, they will at that moment have no more use for the doctrine of the eternal return. For it was nothing more than a psychological apparatus used to get them to this point; but now it can be jettisoned and, for the first time, the full breadth of the will to power can be seen and actualized in living, for the first time, not for the next world or even tomorrow, but for the moment-a moment which unifies the whole of one's existence. It is only in such a state that one can manifest the will to power and experience the full reality of their joys. This is why Nietzsche emphasized the thought as much as he did-it opened one up to truth on so many levels. The eternal return is thus revealed as a mockery of projects of immortality, which conveys its truth in a sublime irony. It lies at the heart of Nietzsche's philosophy as a paradigmatic representative of his sometimes elusive but always potent method. A method which never delineates truth outright, but reveals itself internally, between the lines by cleverly forcing one, in the spirit of Heraclitus, to "search their nature"-a method which escapes Heidegger entirely, and is completely lost in Heidegger's metaphysical analysis of the eternal return. In the words of Richard Howey:

The "coherence" of Nietzsche's philosophy is intelligible only insofar as we understand the notion of Eternal Recurrence dialectically as the attempt to provide a bridge between the two essentially irreconcilable perspectives of life and cosmology. Heidegger's very method of proceeding is, of necessity, frustrated by the most 
fundamental character of Nietzsche's approach to philosophy. (Howey 97)

Perhaps the best insight into understanding Nietzsche's philosophy can be found in Heraclitus' aphorism: "They do not apprehend how being in conflict it still agrees with itself; there is an opposing coherence, as in the tensions of the bow and lyre" (Geldard 157). Whenever Nietzsche's thought appears prima facie to conflict with itself, a coherence often opens up by looking deeper and, in that movement, reveals its truth.

In conclusion, in the published works of Nietzsche's, the eternal return is clearly presented as a psychological thought experiment, not a metaphysical reality - the only evidence to support taking it literally to be found in the unpublished notes of The Will to Power, and there only a hint; hardly enough to refute the psychological interpretation especially considering that such an interpretation conveniently puts Nietzsche in line with Heidegger's own project. Moreover such an interpretation at best compromises other aspects of Nietzsche's philosophy and at worst flies in the face of them, and is achieved only by viewing Nietzsche through the lens of a single unpublished note; add to this the fact that such an interpretation is based on a radical and unjustified reinterpretation of Heraclitus when there is no evidence that Nietzsche subscribed to such an interpretation-while the non-literal interpretation can not only be harmonized with the rest of Nietzsche' thought but in fact reveals the very essence of his philosophy - and the evidence is overwhelming that Heidegger is not only wrong but guilty of nothing less than reckless and dangerous scholarship.

\section{References}

Geldard, Richard, Remembering Heraclitus: Lindisfarne Books; New York, 2000.

Heidegger, Martin, Nietzsche: Trans. by David Ferrell Krell, Harper and Row Publishing; San Francisco, 1984 (Cited throughout by Volume followed by page). 
Howey, Richard Lowell, Heidegger and Jaspers on Nietzsche:

Martinus Nijhoff; The Hague, 1973.

Kundera, Milan, The Unbearable Lightness of Being: Trans.

Michael Heim. Perennial Classics, Harper and Row

Publishing; New York, 1999.

Nietzsche, Friedrich, Beyond Good and Evil: Trans. by R. J.

Hollingdale. Penguin Books; New York, 1990 (Abbreviated

as "BGE" followed by aphorism number).

Nietzsche, Friedrich, The Gay Science: Trans. by Walter Kaufmann.

Random House Publishing; New York, 1974 (Abbreviated as

"GS" followed by aphorism number).

Nietzsche, Friedrich, The Genealogy of Morals: Edited and Trans.

by Walter Kaufman, and R. J. Hollingdale. Vintage Books,

Random House Publishing; New York, 1989. (Abbreviated

as "GM" followed by aphorism number)

Nietzsche, Friedrich, Human All Too Human: Trans. R. J.

Hollingdale, Cambridge University Press; New York, 1996.

(Abbreviated "HH" followed by aphorism number).

Nietzsche, Friedrich, The Portable Nietzsche: Edited and Trans.

by Walter Kaufmann. Penguin Books; New York, 1954 (Abbreviated as "PN").

Nietzsche, Friedrich, The Will to Power: Edited and Trans. by Walter Kaufman and R. J. Hollingdale. Vintage Classics, Random House Publishing; New York, 1967. (Abbreviated as "WP" followed by aphorism number). 